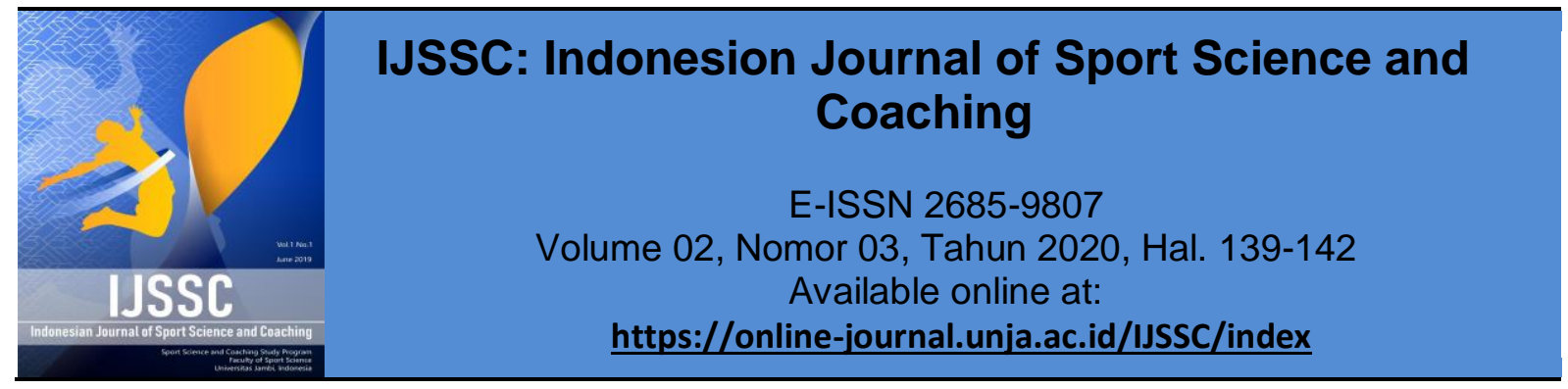

Research Article

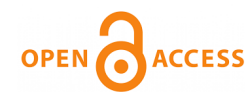

\title{
Tantangan dan Solusi Pembelajaran Daring Olah Raga di Masa Pandemi Covid-19
}

(Sports Online Learning Challenges and Solutions during the Covid-19 Pandemic)

Boy Indrayana*, Ali Sadikin

Universitas Jambi

Kampus Pinang Masak, Jl. Jambi-Ma.Bulian KM.15 Mendalo Indah

Kec.Jaluko Kab.Muaro Jambi, Jambi-Indonesia 36361

*corresponding author : alisadikin@unja.ac.id

\begin{tabular}{|c|c|}
\hline Informasi Artikel & ABSTRACT \\
\hline \multirow[t]{2}{*}{$\begin{array}{l}\text { Submit: } 13-01-2020 \\
\text { Diterima: } 30-06-2020 \\
\text { Dipublikasikan: } 09-11-2020\end{array}$} & $\begin{array}{l}\text { With the Covid-19 pandemic, it provides an experience that learning should be } \\
\text { done face-to-face and online. The purpose of this study was to determine learning } \\
\text { about sports during the Covid-19 pandemic. The method used is descriptive } \\
\text { qualitative. With data collection procedures, data reduction, drawing conclusions } \\
\text { and reporting. The results showed that learning using zoom cloud meetings was } \\
\text { more popular with students and lecturers than other online media. }\end{array}$ \\
\hline & Key words: Sports Education, Pandemic, Covid-19 \\
\hline Penerbit & ABSTRAK \\
\hline \multirow[t]{2}{*}{$\begin{array}{l}\text { Jurusan Pendidikan Olah Raga dan } \\
\text { Kepelatihan FKIP Universitas Jambi } \\
\text { Jambi- Indonesia }\end{array}$} & $\begin{array}{l}\text { Dengan adanya pandemi Covid-19 memberikan pengalaman bahwa pembelajaran } \\
\text { sebaiknya dilakukan secara tatap muka dan secara on line. Tujuan penelitian ini } \\
\text { adalah untuk mengetahui pembelajaran olah raga di masa pandemi Covid-19. } \\
\text { Metode yang digunakan adalah diskriptif kualitatif. Dengan prosedur pengumpulan } \\
\text { data, reduksi data, penarikan kesimpulan dan pelaporan. Hasil penelitian } \\
\text { menunjukkan bahwa pembelajaran menggunakan zoom cloud meeting lebih } \\
\text { digemari mahasiswa dan dosen dibandingkan media on line yang lain. }\end{array}$ \\
\hline & Kata kunci: Pendidikan Olahraga, Pandemi, Covid-19 \\
\hline
\end{tabular}

This IJSSC : Indonesian Journal of Sport Science and Coaching is licensed under a CC BY-NCSA (Creative Commons Attribution-ShareAlike 4.0 International License)

\section{PENDAHULUAN}

Di masa pandemi Covid-19, lembaga pendidikan mengalami kesulitan untuk menyelenggarakan pendidikan secara on line (Asmuni, 2020). Hal ini dikarenakan belum adanya sarana dan prasarana yang memadai untuk mengatasi masalah tersebut (Jamaluddin et al., 2020; Pangondian et al., 2019). Ditambah lagi, kemampuan sumber daya manusia guru dan dosen belum terbiasa dengan pembelajaran jarak jauh. Kondisi ini akan menyulitkan baik bagi guru maupun siswa 
dan orang tua siswa. Dari guru akan kesulitan menyiapkan bahan ajar, media dan pengawasan. Dari siswa belum terbiasa dengan pola daring, tugas yang menumpuk, motivasi belajar yang menurun karena akan jenuh dan bosan. Dari segi orang tua akan kerepotan dalam membantu anaknya dalam mempersiapkan media atau gadget, membimbing dan mengarahkan dalam mengerjakan tugas dari guru dan memotivasi serta mengawasi anaknya dalam mengikuti pelajaran.

Akan tetapi dalam kondisi bagaimana pun proses pembelajaran bagi anakanak peserta didik harus tetap berlangsung. Walaupun dalam kondisi pandemi covid19 yang tidak kunjung berakhir ini. Penerapan protokol kesehatan dengan selalu memakai masker, menjaga jarak, mencuci tangan dan menghindari kerumunan massal seperti sekolah, tempat ibadah, pasar, dan acara hiburan(Rothan \& Byrareddy, 2020). Lalu apakah kondisi ini berlaku juga dalam perkuliahan di perguruan tinggi perlu diadakan penelitian untuk mengungkap fakta keterlaksanaan dan kesulitan pembelajaran daring di masa pandemi covid-19 ini.

\section{METODE PENELITIAN}

Metode penelitian menggunakan deskriptif kualitatif. Menggambarkan pembelajaran pendidikan olahraga di Jurusan Pendidikan Olahraga dan kepelatihan FKIP Universitas Jambi di masa pandemi covid-19. Subyek penelitian mahasiswa jurusan pendidikan olahraga dan kepelatihan FKIP Universitas Jambi. Instrumen penelitian wawancara. Analisis data meliputi: pengumpulan data, reduksi, dan penarikan kesimpulan serta pelaporan (Sugiyono, 2016).

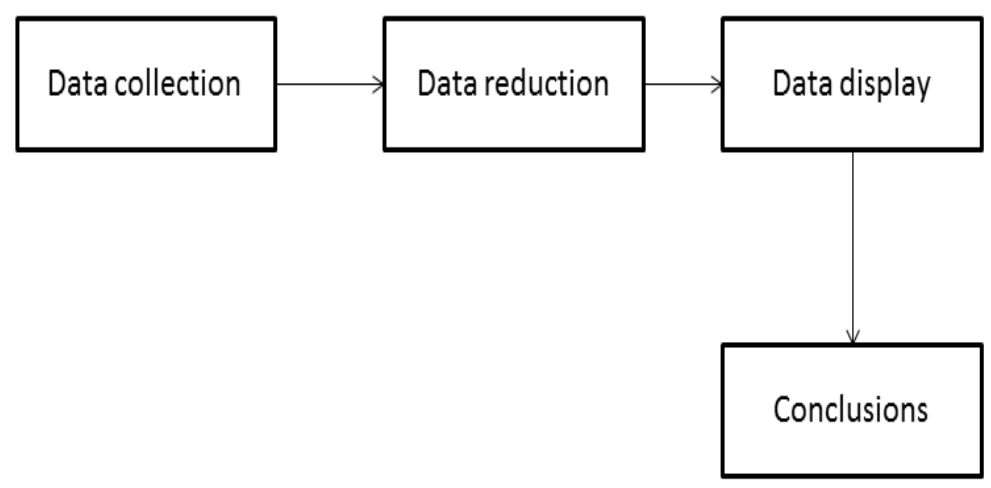

\section{HASIL DAN PEMBAHASAN}

Berdasarkan wawancara kepada mahasiswa dan dosen yang melakukan perkuliahan secara daring di Jurusan Pendidikan Olah Raga dan Kepelatihan FKIP Universitas Jambi. Dosen mengalami kesulitan dalam pelaksanaan pembelajaran daring. Kesulitan itu meliputi penguasaan media daring atau on line untuk melaksanakan pembelajaran, penyiapan bahan ajar dan kesediaan alat atua instrumen evaluasi serta pengawasan terhadap mahasiswa juga menjadi hambatan dan tantangan.

Kesulitan dari mahasiswa adalah biaya kuota yang mahal, jaringan internet di desa yang sulit, banyak tugas yang menumpuk dan motivasi belajar yang menurun. 
Lalu bagaimana menghadapi permasalah ini, perguruan tinggi menyediakan panduan dan sosialisasi pembelajaran daring. Pemerintah membantu penyediaan kuota internet baik bagi mahasiswa maupun dosen. Kemudian, dosen juga mencoba untuk belajar menyediakan bahan ajar on line dan instrumen penilaian untuk pembelajaran daring. Mahasiswa juga dipaksa untuk mampu belajar daringk dengan kondisi yang ada. Mahasiswa yang kesulitan sinyal harus mencari sinyal ke kecamatan atau ke kota supaya bisa mengikuti. Pembelajaran daring memiliki kesulitan dari segi sarana dan prasarana misalnya jaringan internet (Jamaluddin et al., 2013, 2020).

Dengan pembelajaran daring ini maka penyebaran covid-19 dapat dihindari karena dosen dan mahasiswa tidak bertemu dan bertatap muka. Interaksi antar mahasiswa pun dapat terhindar sehingga kontak langsung bisa dihindari dan penyebaran covid-19 bisa dihindari. Adapun media on line yang digunakan oleh mahasiswa Jurusan Olah raga dan Kepelatihan FKIP Universitas Jambi adalah zoom cloud meeting, google clasroom, google meet, moodle, LMS Universitas Jambi dan whatshap. Penggunaan zoom cloud meeting memudahkan dalam proses pembelajaran daring (Naserly, 2020)

Berdasarkan wawancara mahasiswa dan dosen lebih menggemari penggunaan aplikasi zoom cloud meeting. Hal ini dikarenakan aplikasi atau media ini lebih mudah digunakan, lebih familiar, gambarnya bagus, mudah menampilkan materi, mudah berkomunikasi dan tatap muka. Sehingga mahasiswa lebih mudah memahami materi pelajaran. Penerapan zoom cloud meeting dapat meningkatkan pemahaman mahasiswa terhadap materi pelajaran(Zannah et al., 2014). Dibandingkan dengan media lain seperti google clasroom jarang mahasiswa membuka dan kurang familiar, mahasiswa dan dosen tidak dapat bertatap muka secara virtual, begitu pun moodle, LMS Universitas Jambi dan whatshap. Google meet sama-sama dapat bertatap muka tetapi gambar atau tampilan visual kurang baik.

\section{KESIMPULAN}

Dengan adanya pandemi Covid-19 memberikan pengalaman bahwa pembelajaran sebaiknya dilakukan secara tatap muka dan secara on line. Tujuan penelitian ini adalah untuk mengetahui pembelajaran olah raga di masa pandemi Covid-19. Metode yang digunakan adalah diskriptif kualitatif. Dengan prosedur pengumpulan data, reduksi data, penarikan kesimpulan dan pelaporan. Hasil penelitian menunjukkan bahwa pembelajaran menggunakan zoom cloud meeting lebih digemari mahasiswa dan dosen dibandingkan media on line yang lain.

\section{DAFTAR PUSTAKA}

Asmuni, A. (2020). Problematika Pembelajaran Daring di Masa Pandemi Covid-19 dan Solusi Pemecahannya. Jurnal Paedagogy, 7(4), 281-288.

https://doi.org/https://doi.org/10.33394/jp.v7i4.2941

Jamaluddin, D., Ratnasih, T., Gunawan, H., \& Paujiah, E. (2013). Pembelajaran Daring Masa Pandemik Covid-19 Pada Calon Guru: Hambatan, Solusi Dan Proyeksi. Journal of Chemical Information and Modeling, 53(9), 1-10. 
https://doi.org/10.1017/CBO9781107415324.004

Jamaluddin, D., Ratnasih, T., Gunawan, H., \& Paujiah, E. (2020). Pembelajaran

Daring Masa Pandemik Covid-19 Pada Calon Guru : Hambatan, Solusi dan

Proyeksi. Karya Tulis IImiah UIN Sunan Gunung Djjati Bandung, 1-10.

http://digilib.uinsgd.ac.id/30518/

Naserly, M. K. (2020). IMPLEMENTASI ZOOM, GOOGLE CLASSROOM, DAN

WHATSAPP GROUP DALAM MENDUKUNG PEMBELAJARAN DARING

(ONLINE) PADA MATA KULIAH BAHASA INGGRIS LANJUT (Studi Kasus Pada

2 Kelas Semester 2, Jurusan Administrasi Bisnis, Fakultas Ekonomi dan Bisnis,

Universitas Bina Sa. Aksara Public, 4(2), 155-165.

Pangondian, R. A., Paulus, S. I., \& Nugroho, E. (2019). Faktor - Faktor Yang

Mempengaruhi Kesuksesan Pembelajaran Daring Dalam Revolusi Industri 4.0.

Seminar Nasional Teknologi Komputer \& Sains (SAINTEKS), 56-60.

https://seminar-id.com/semnas-sainteks2019.html

Rothan, H. A., \& Byrareddy, S. N. (2020). The epidemiology and pathogenesis of coronavirus disease (COVID-19) outbreak. Journal of Autoimmunity, 102433. https://doi.org/https://doi.org/10.1016/j.jaut.2020.102433

Sugiyono. (2016). Metode Penelitian Kuantitatif, Kualitatif dan R\&D. Alfabeta.

Zannah, P. Z., Mulhayatiah, D., \& Alatas, F. (2014). Penggunaan media pembelajaran zooming presentation untuk meningkatkan hasil belajar siswa kelas x pada konsep suhu dan kalor. EDUSAINS, 6(2), 211-216. 